\title{
Mihin jäi tasa-arvoisuus aikuiskoulutuksen kehittämisessä?
}

Vihdoinkin vaikuttaa siltä, että kaikki tahot olisivat yksimielisiä aikuiskoulutuksen asettamisesta koulutusjärjestelmän kehittämistyön keskipisteeksi. Kaikki 1970-luvun hienot esitykset ja suunnitelmat on nyt otettu uudelleen esiin. Niitä on täydennetty päätöksillä, jotka täsmentävät aikuiskoulutuksen rahoittamista ja edelleenkehittämistä. Mutta mitä on esitetty jo aikaisemmin ja mitä pitäisi tehdä tulevaisuudessa?

Aikuiskoulutuskomitea totesi mm., että on pyrittävä kehittämään työelämän koulutusta. Vapaan sivistystyön ohella on panostettava voimakkaasti ammatilliseen aikuiskoulutukseen. Valtioneuvosto yhtyi tähän käsitykseen vuonna 1978 tekemässään periaatepäätöksessä. Samassa päätöksessä valtioneuvosto korosti jatkuvan koulutuksen periaatetta, persoonallisuuden monipuolista kehittämistä sekä koulutuksellisen tasa-arvon lisäämistä keskeisinä seikkoina aikuiskoulutuksen suunnittelussa ja kehittämisessä.

Moni aikuiskoulutuksen jonkin osa-alueen toimikunta on tämän jälkeen tehnyt lukuisia hyviä ehdotuksia, mutta miltei kaikki odottavat vielä toteuttamistaan. Aikuiskoulutuksen kehittäminen on saanut uutta vauhtia sen jälkeen, kun valtioneuvosto rakennemuutoskeskustelun myötävaikutuksesta vuosina 1987 ja 1988 teki uudet periaatepäätökset ammatillisen aikuiskoulutuksen rahoittamisesta ja kehittämisestä. Ns. omaehtoisessa koulutuksessa ei näytä tapahtuvan periaatteellisia muutoksia, vaan jatkossakin yhteiskunta (valtio ja kunta) vastaa sen tarjonnasta. Työllisyyskoulutuksen kustannukset maksaa edelleen valtio. Tulevaisuudessa kuitenkin työvoimahallinto ostaa koulutuksen lähinnä ammatillisilta kurssikeskuksilta, jotka muuttuvat aikuiskoulutuskeskuksiksi, mutta myös muilta mahdollisilta koulutuksen järjestäjiltä. Lisäksi valtioneuvosto on päättänyt, että työnantaja maksaa henkilöstökoulutuksen kokonaisuudessaan riippumatta siitä, onko työnantaja yksityinen, kunta, valtio tai seurakunta.
Periaate, jonka mukaan työnantaja vastaan henkilöstökoulutuksestaan ei ole uusi. Mutta uutta on se, että aikuiskoulutusta järjestävät laitokset - ammatilliset oppilaitokset, kurssikeskukset, korkeakoulut ja vapaan sivistyksen piiriin kuuluvat laitokset - rupeavat työnantajan toimeksiannosta tilaustyönä myymään henkilöstökoulutusta. Yhteiskunta tulee jatkossakin subventoimaan pienyritysten henkilöstökoulutusta sekä vähän kysyttyä koulutusta.

Mielestäni on arvokasta, että on päästy aikaisempaa konkreettisemmin kehittämään ammatillista aikuiskoulutusta. Vanhat kehittämisesitykset muodostavat hyvän pohjan jatkotyöskentelylle ja työnjako aikuiskoulutuksen rahoittamisessa on oikeansuuntainen. Kuitenkin olen jäänyr kaipaamaan syvää koulutuspoliittista keskustelua aikuiskoulutuksen ydinkysymyksestä. Miten voidaan koulutuksellista tasaarvoisuutta toteuttaa aikuiskoulutuksen avulla, kun ammatillista aikuiskoulutusta tullaan kehittämään markkinatalouden termeillä? Eli miten tuetaan jatkossa rahatonta ja koulutuksetonta kun se, jolla on rahaa, ostaa ja myös päättää, kenelle ostetaan ja mitä.

Kaikki selvitykset osoittavat, että sekä henkilöstökoulutus että omaehtoinen koulutus suosivat niitä, jotka ovat jo ennestään hyvin koulutettuja. Nuoret, kauniit, vähintään yrityksen keskijohtoon kuuluvat miehet saavat työnantajan kustantamaa koulutusta. Peruskoulutuksena järjestettävä ammatillinen aikuiskoulutus kerää usein nuorempaa väkeä, jolla on jo takanaan jokin tutkinto.

Yleissivistävä aikuiskoulutus houkuttelee etupäässä naisia, joilla ennestään on hyvä koulutuspohja ja jotka tarvitsisivat pikemminkin ammattiuraa kehittävää koulutusta.

On tietenkin totta, että koulutuksella ja aikuiskoulutuksella on hyvin rajatut mahdollisuudet edistää tasa-arvoisuutta yhteiskunnassa, joka ei ole tasa-arvoinen. Koulutus ei pysty korjaamaan kaikkea. Mutta silti toivoisin, että voisimme tulevina vuosina pohtia, miten tukea väliinputoajia ja myös toimia niin, että voima- 
varoja kohdistetaan vähiten koulutusta saaneille laajan hakevan toiminnan kautta.

Kun työllisyyskoulutus järjestetään siten, että työvoimahallinto rupeaa ostamaan koulutusta työttömille ja työttömyysuhan alaisille, toivon hartaasti, ettei yksittäistä työtöntä unohdeta. Toivottavasti yritykset laajentavat henkilökoulutustaan työnantajan ja työntekijöiden välisenä yhteistyönä. Toivon niinikään, että tällöin muistetaan myös vanhempia, ilman koulutusta olevia, ei enää niin "kauniita" työntekijöitä, jotka usein ovat naisia. Iskulause "ihminen työpaikan tärkein voimavara" pitää näkyä myös työpaikan koulutuksessa. Ja kun organisaatiot tarjoavat valtion ja kuntien puolesta omaehtoista aikuiskoulutusta, on ensiarvoisen tärkeää, että aktiivisen etsimisen kautta suunnataan koulutusta niille, jotka kipeästi sitä tarvitsevat. Tähän suureen kysymykseen opetusviranomaisten pitää jatkossa keskittää voimiaan yhdessä työvoimaviranomaisten ja työelämän edustajien kanssa. Muuten koulutuskuilut eri ikäryhmien, työssä käyvien ja työelämän ulkopuolella olevien välillä kasvavat edelleen. Vai onko tarkoitus muuttaa tähänastista varsin yksimielisesti hyväksyttävä koulutuspolitiikkaa?

Lopuksi muutama sana yleissivistävän ja ammatillisen koulutuksen rajankäynnistä. Ihminen tarvitsee työelämässä sekä yleistä että eri työtehtäviin suuntautunutta koulutusta. Aikuiskoulutuksen päätehtävänä ei voi olla ihmisen sopeuttaminen muutoksiin, joista harva päättää ja joihin muut saavat tyytyä, vaan sen pitää antaa edellytyksiä jokaiselle olla mukana vaikuttamassa omaan ympäristöönsä ja sen kehittämiseen. Tämä koskee tietenkin myös ammatillista aikuiskoulutusta, joka olisi nähtävä laajasti.

Mielestäni ei ole kovin hedelmällistä käydä keskustelua siitä, mikä aikuiskoulutusmuoto antaa sivistystä ja mikä ei. Kaikki koulutus kehittää persoonallisuutta. Maailman lyseo on tärkein kehittäjä. Pääsiäisen tienoilla tätä kirjoittaessani jään miettimään, saanko enemmän sivistystä, ilmoittautumalla kansalaisopiston pääsiäismunakoristekurssille vai maatalousoppilaitoksen kanalahoitajien jatkokoulutukseen. Ottamatta kantaa kananmunien ylituotanto-ongelmaan totean, että voin tarvita molempia.

Jos haluamme parantaa aikuisväestön mahdollisuuksia kehittyä ja kehittää, tarvitaan tiivistä yhteistyötä aikuiskoulutuksen eri laitosten ja lohkojen välillä. Opetusministeriön käynnistämän nuorisokoulukeskustelun jatkeeksi pitää ruveta madaltamaan raja-aitoja myös eri aikuiskoulutusmuotojen välillä, ei ainoastaan hallinnollisesti, vaan myös asenteellisesti. 